
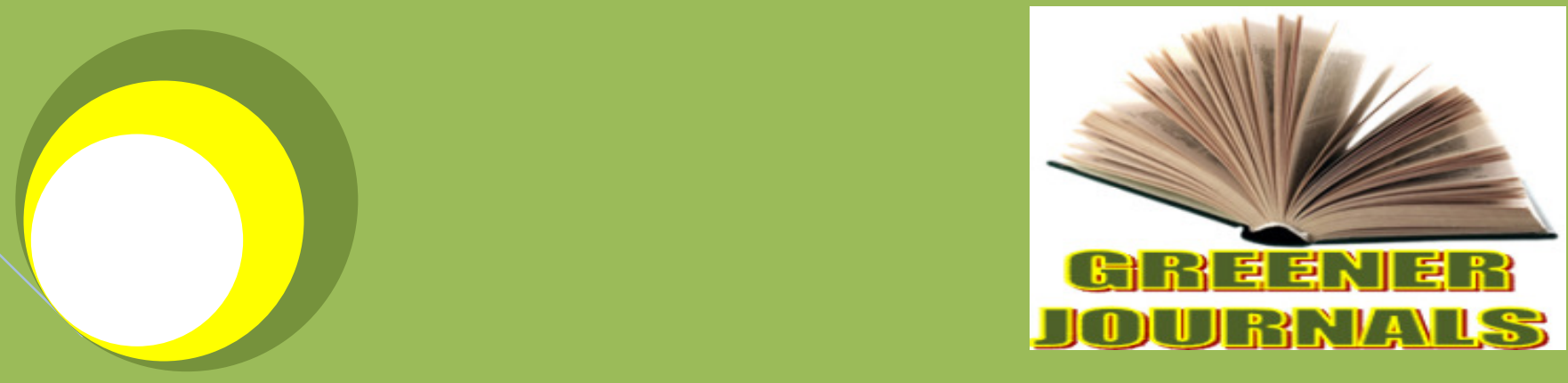

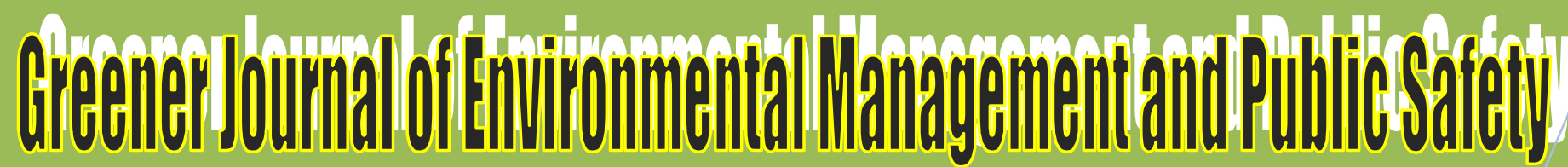
ISSN: 2354-2276

\title{
Pesticide Preferences and Pattern of Use along the Shore of Lake Naivasha, Kenya
}

By

Njoroge Simon Mburu Odipo Osano

Munyao Thomas Munyao Chege Moses Gichuho 


\title{
Pesticide Preferences and Pattern of Use along the Shore of Lake Naivasha, Kenya
}

\section{Njoroge Simon Mburu ${ }^{1 *}$, Munyao Thomas Matuku², Odipo Osano ${ }^{3}$, Chege Moses Gichuho ${ }^{4}$}

\author{
${ }^{1 *}$ School of Public Health, Moi University, Kenya \\ ${ }^{2,3,4}$ School of Environmental Studies, Moi University, Kenya
}

${ }^{1 *}$ Corresponding Author's Email: njorogesmburu@gmail.com, Tel: +254 722886702

\begin{abstract}
Improper pesticide application has resulted in high toxicity levels causing environmental risk. The objective of the study was to determine pesticide preferences and pattern of use in farms along the shore of Lake Naivasha. Interviewer administered questionnaires and researcher observation were used to collect data on pesticides being used and pattern of use in $\mathbf{2 0}$ major horticultural farms around Lake Naivasha. Secondary data from journals, standards and materials safety data sheets from manufacturers were also used to determine pesticide properties such as toxicity. The results showed there were $4.3 \%$ (6) WHO class I and $14.3 \%$ (20) class II pesticides of the 141 pesticides used along the shore of Lake Naivasha. The pattern of pesticide use in the area was moderate to high and all the farms were also using Integrated Pest Management (IPM) to control pests. It was concluded that some pesticides in WHO class I that were being used along the shore of Lake Naivasha (e.g. oxamyl, methomyl and fenamiphos) are very toxic to human beings and aquatic organisms since they cause cholinesterase inhibition poisoning by inactivating the enzyme acetylcholinesterase.
\end{abstract}

Keywords: Pesticides, Environmental pollution, integrated pest management, Lake Naivasha.

\section{INTRODUCTION}

Lake Naivasha is located in Nakuru County in the Eastern Rift Valley, about 100km Northwest of Nairobi, Kenya's capital. Lake Naivasha has a farming system that is well expanded in the riparian zone. Bordering the lake are some of the biggest flower farms in the world. The irrigated areas increased from 981.8 ha in 1988 to 7353 ha by 1997 (Tang, 1999). Eighty percent $(80 \%)$ of the Kenya's horticultural production is found in the Lake basin, making it the most important area for cut flowers in Kenya (Jolicoeur, 2000).

Agricultural products, especially the ones produced for export have to match a high quality standard. To achieve these quality standards it is necessary to have a good program of weed control and pest management. The use of pesticides is one of the most used tools to achieve it. But improper pesticide application results in high toxicity levels causing environmental risk.

Pesticides are chemicals that are used in agriculture and public health for the control of pests, weeds, plant diseases, animals and vectors of diseases (FAO, 1986). These chemicals may be extracted from plants or may be synthetic. Synthetic pesticides present potential hazards to public health. Some pesticides are used both in agriculture and as vector control agents in public health programmes. Agriculture and horticulture, together with vector control programmes, account for the greatest use of pesticides (WHO, 1990). Significant amounts are also used in forestry and livestock production. According to U.S. EPA Pesticide Industry Sales and Usage Report, 1.23 billion pounds active ingredient of conventional and other pesticide chemicals were applied in the U.S. in 1997 (Aspelin and Grube, 1999). Furthermore, 77\% (or 944 million pounds) of the chemicals were designated specifically for agricultural use (Aspelin and Grube, 1999).

Investigation on Pesticide preferences and their pattern of use along the shore of Lake Naivasha is presented in this study. This was accomplished by determining the types of pesticides used; their WHO toxicity classification and the pattern of use. The pattern of use was assessed based on the tool developed by Wachter and Staring (1981) using the following parameters: pesticide products and level of use; source and distribution structure of pesticide used in the farms; area of land under pesticide use and; laws and regulations applicable to pesticides in Kenya. 


\section{MATERIAL AND METHODS}

All the twenty (20) major horticulture farms in Lake Naivasha basin were targeted. The farms that agreed to participate in the study were asked to choose the personnel handling pesticides to fill the questionnaires. Purposive sampling method was used to ensure that only the farms within the major horticultural farms were included in the study.

Interviewer administered questionnaires and researcher observation were used to collect data on pesticide use and preferences, pattern of use and other methods used to control weeds, pests and plant diseases. Literature materials (journals, standards and materials safety data sheets from manufacturers) were also used to determine pesticide properties such as toxicity. The questionnaires were administered to the personnel handling pesticides in the farms that agreed to participate in the study. Some small scale farms were also included where key informants were interviewed. Consent to conduct the study was sought from Moi University's School of Environmental Studies and Lake Naivasha Riparian owner's Association (LNROA).

\section{RESULTS}

\section{Pesticide use and preferences}

All farms interviewed reported that they used pesticides to control weeds, pests and plant diseases. Some pesticides were used to control a wide range of pests, weeds and plant diseases in the various horticultural crops grown around Lake Naivasha.

The number of pesticides found to be in use along the shore of Lake Naivasha were 141 and in all classes (IIV) given by WHO. There were $4.3 \%$ (6) class I and $14.3 \%$ (20) class II pesticides identified as being used along the shore of Lake Naivasha (Table 1). Class I pesticides identified in this study belonged to six chemical groups namely; carbamates, bipyridylium, strobilurin, tetranortriterpenoids, azole and organophosphates.

Table 1: Class I and II pesticides used along the shores of Lake Naivasha

\begin{tabular}{|c|c|c|c|c|c|c|c|}
\hline $\begin{array}{l}\text { S. } \\
\text { No. }\end{array}$ & Trade Name & Chemical name & \begin{tabular}{|l|} 
WHO \\
Class \\
\end{tabular} & CAS No. & \begin{tabular}{|l|} 
Group \\
(Chemical type)
\end{tabular} & \begin{tabular}{|l|} 
application \\
rate/Ha/yr \\
\end{tabular} & Use/type \\
\hline 1 & Fastac & Alpha cypermethrin & II & $67375-30-8$ & Pyrethroid & $1600 \mathrm{mls}$ & insecticide \\
\hline 2 & Bulldock 025EC & Beta cyfluthrin & II & $68359-37-5$ & Pyrethroid & $2000 \mathrm{mls}$ & Insecticide \\
\hline 3 & Brigade, Tals tar $100 \mathrm{Ec}$ & Befenthrin & II & $82657-04-3$ & Pyrethroid & $1600 \mathrm{mls}$ & insecticide \\
\hline 4 & Decis, Keshet 2.5EC & Deltamethrin & II & $52918-63-5$ & Pyrethroid & $1000 \mathrm{mls}$ & insecticide \\
\hline 5 & Karate & Lambda cyhalothrin & II & $91465-08-6$ & Pyrethroid & $1000 \mathrm{mls}$ & insecticide \\
\hline 6 & Mavrik & Taufluvalinate & II & 102851-06-9 & Pyrethroid & $360 \mathrm{mls}$ & insecticide \\
\hline 7 & Vydate & Oxamy 1 & Ia & $23135-22-0$ & Carbamate & $28000 \mathrm{gms}$ & $\begin{array}{l}\text { Insecticide, } \\
\text { nematicide }\end{array}$ \\
\hline 8 & Lannate & methomyl & $\mathrm{Ib}$ & $16752-77-5$ & Carbamate & & Insecticide \\
\hline 9 & Gramoxone & Paraquat & $\mathrm{Ib}$ & $1910-42-5$ & bipy ridy lium & $9200 \mathrm{mls}$ & Herbicide \\
\hline 10 & Stroby & Kresoxim-methyl & $\mathrm{Ib}$ & $143390-89-0$ & strobilurin & $2000 \mathrm{gms}$ & Fungicide \\
\hline 11 & systhane & myclobutanil & $1 \mathrm{~b}$ & 88671-89-0 & Azole & & Fungicide \\
\hline 12 & Secure $360 \mathrm{Sc}$ & Chlorfenapyr & II & $122453-70-0$ & organophosphate & $800 \mathrm{gms}$ & Insecticide \\
\hline 13 & Pyrinex & Chlorpyrifos & III & $2921-88-2$ & organophosphate & $1920 \mathrm{gms}$ & Insecticide \\
\hline 14 & Spidermec 018 EC & Abamectin & II & $71751-41-2$ & $\begin{array}{l}\text { soil bacterium } \\
\text { streptomyces }\end{array}$ & $2000 \mathrm{mls}$ & Acaricide \\
\hline 15 & Pegasus $500 \mathrm{SC}$ & Diafenthiuron & II & $80060-09-9$ & thiourea & $2400 \mathrm{mls}$ & Acaricide \\
\hline 16 & Rubigan & Fenarimol & II & 060168-88-9 & pyrimidine & $1200 \mathrm{mls}$ & Fungicide \\
\hline 17 & Pyrus & Pyrimethanil & II & $53112-28-0$ & anilinopy rimidine & $1600 \mathrm{gms}$ & Fungicide \\
\hline 18 & Impuls e & Spiroxamine & II & $118134-30-8$ & s piroketalamine & $4000 \mathrm{mls}$ & fungicide \\
\hline 19 & Meltatox & Dodemorph acetate & II & $31717-87-0$ & morpholine & $10000 \mathrm{mls}$ & fungicide \\
\hline 20 & Pride & Fenazaquin & II & $120928-09-8$ & quinazoline & $2000 \mathrm{mls}$ & fungicide \\
\hline 21 & \begin{tabular}{|l} 
Teldor \\
\end{tabular} & Fenhexamid & II & $126833-17-8$ & Hydroxyanilide & $4000 \mathrm{gms}$ & Fungicide \\
\hline 22 & Milberknock & Milbemectin & II & 51596-11-3 & Biopesticide & $2000 \mathrm{mls}$ & Acaricide/ \\
\hline 23 & Kohinor, Confidor & Imidacloprid & II & 138261-41-3 & chloro-nicotinyl & $2000 \mathrm{gms}$ & insecticide \\
\hline 24 & Dicap & Dimethoate & II & $60-51-5$ & organophosphate & & insecticide \\
\hline 25 & Nemacur & Fenamiphos & Ia & $22224-92-6$ & organophosphate & & insecticide \\
\hline 26 & Daconil & Chlorothalon1l & III & $1897-45-6$ & chlorinated & $8000 \mathrm{mls}$ & Fungicide \\
\hline
\end{tabular}




\section{Development pattern of pesticide use}

The results of development pattern of pesticide use are given in Table 2 below based on the pattern developed by Wachter and Staring (1981). Table 2 summarizes the percentage responses from farms around Lake Naivasha.

Table 2: Development pattern of pesticide use around Lake Naivasha

\begin{tabular}{|c|c|c|c|c|c|c|c|c|}
\hline Variable & $\mathrm{J}(\%)$ & K (\%) & $L(\%)$ & M (\%) & $\mathrm{N}(\%)$ & $\mathbf{P}(\%)$ & $Q(\%)$ & Total \\
\hline \multicolumn{9}{|l|}{ Pattern of pesticide } \\
\hline Stage I (Very Low) & 33.3 & 25 & & & & & & 58.3 \\
\hline Stage II (Low) & 50 & 75 & & & & & & 125 \\
\hline Stage III (Moderate) & 16.7 & & 28.6 & 12.5 & 62.5 & 60 & 25 & 205.3 \\
\hline Stage IV (High) & & & 71.4 & 12.5 & 37.5 & 7.1 & 75 & 203.5 \\
\hline Stage V (VeryHigh) & & & & 75 & & 32.9 & & 107.9 \\
\hline Totals & 100 & 100 & 100 & 100 & 100 & 100 & 100 & 700 \\
\hline
\end{tabular}

Key

$\mathrm{J}: \quad$ Range (products) of pesticides used in farms

K: $\quad$ Source of pesticides used in farms

L: $\quad$ Distribution structure of pesticide used around Lake Naivasha

M: $\quad$ Area of land under pesticide use

$\mathrm{N}$ : $\quad$ Laws and regulations applicable to pesticides in Kenya

P: $\quad$ Level of use pesticide in farms around Lake Naivasha.

Q: $\quad$ Level of agricultural development

The percentages reported for each indicator of development pattern of pesticide use in stages I to $\mathrm{V}$ (very low to very high patterns) were compared to arrive at a single level that could describe the pattern of use along the shore of Lake Naivasha. Stage III (moderate) and stage IV (high pattern) of pesticide use were found to be the highest (Table 2), indicating the pattern of pesticide use along the shore of Lake Naivasha to be moderate to high.

\section{Other methods of pest, weeds and disease control}

The respondents were asked whether their farms use other methods apart from pesticides to control pests, weeds and plant diseases. All the farms reported they used other methods. Weeds were controlled by mechanically removing them from field by hands and weeding tools.

All the farms were using Integrated Pest Management (IPM) to control pests. This involved the use of biological methods such as natural predators and antaporistics such as Trichoderma spp, Paecilomyces spp, Phytoselius perimilis and Amlolysius spp. Entamopathogenic fungi and biopesticides were also used. Other methods of control included monitoring (scouting), washing of whiteflies using pure water, use of barriers and traps and handpicking of caterpillars from the plants.

Plant diseases were controlled by methods such as uprooting of the infected plants to prevent the disease from spreading to the healthy ones, pruning of the infected parts of the plant and planting resistant varieties. The use of greenhouses acted as physical cover that prevented the spread of plant diseases from one greenhouse to another. Heating in greenhouses reduced moisture build-up and this in turn controlled plant diseases.

When asked how they compared harvest when other control methods mentioned above were used alone, $62.5 \%$ of farms reported that harvests were average, $25 \%$ reported below average harvest while only $12.5 \%$ got high yields. They therefore used these other methods to complement pesticide use. 


\section{DISCUSSION}

About $18.6 \%$ (26) of the 141 pesticides being used around lake were in WHO classes I and II: (extremely hazardous (la) $-0.7 \%$, highly hazardous (Ib) $-3.6 \%$ and moderately hazardous (II) $-14.3 \%$ ) (Table 1 ). Although pesticides in these classes are hazardous, farmers still preferred using them possibly due to their effectiveness in pest and disease control and their application to a wide variety of crops (US EPA, 2007). Pesticides in these classes are also highly persistence and bioaccumulate (US EPA, 2007). Some class I pesticides such as oxamyl and methomyl were identified as belonging to the carbamates group (Table 1). The two pesticides were detected in groundwater sampled in the same area (Njoroge, 2012). Carbamate pesticides can cause cholinesterase inhibition poisoning by reversibly inactivating the enzyme acetylcholinesterase (Nathaniel et al., 2006; Mohammad, 2007). This can give rise to a large number of clinical effects in the central nervous system, autonomic nervous system and may lead to paralysis (Nathaniel et al., 2006; Mohammad, 2007).

This study also showed that paraquat (WHO class I) which is a bipyridylium herbicide was also a preferred pesticide. This pesticide has been shown to affect the lungs even in very small doses (Fishel, 2008). Its large application rate of 9.2L/ha/year along the shore of Lake Naivasha is of concern given its high toxicity. Myclobutanil (WHO class I) was also a preferred pesticide even though it has been shown to be teratogenic, inducing facial, axial skeleton, and limb defects (Giavini and Menegola, 2010). It is also known to affect endocrine systems of different organisms and this is the reason for environmental concern (Maren et al., 2008).

Class II pesticides with WHO toxicity classification of moderately hazardous (harmful or fatal) are now widely used as many regulatory organizations on pesticide use continue to discourage the use of class I chemicals. Class III pesticides with WHO toxicity classification of slightly hazardous (harmful) were found to be widely used in large quantities in the study area. Though considered less harmful, some pesticides in this class can be harmful if high doses are taken (WHO, 2011).

\section{Pattern of development of pesticide use}

The pattern of development of pesticide use in Lake Naivasha basin was moderate to high (Table 2). This is in agreement with general economic development of Kenya, a developing country (Wachter, and Staring, 1981). Other areas of the country are likely to have a low pattern since Lake Naivasha basin is a region where pesticides are extensively used compared to other regions of the country. In terms of the level of use of pesticides $32.9 \%$ farms had a pattern of development of 'very high' (active ingredient over $5 \mathrm{~kg} / \mathrm{ha}$ ). Seventy five percent $(75 \%)$ of farms have over $90 \%$ of land area under pesticide use exhibiting very high pattern. These individual patterns of pesticide development are very high for a developing country like Kenya.

A large percentage $(62.5 \%)$ of respondents said they were aware that Kenya has laws and regulations but which were not adequately enforced. The farms used mainly imported formulated products, but a few products formulated locally. In the developed countries, stringent legal requirements regarding toxicological and ecological effects have to be satisfied before the importation and use of any particular pesticide is permitted. The costs of satisfying these requirements, when a new pesticide is being developed are very high. Before approving the use of a specific pesticide, the responsible government agency may require that the manufacturer provides data from standard animal toxicity tests and from field studies of ecological effects and environmental transfer (WHO, 1990).

\section{Other methods of control}

All of the farms were using Integrated Pest Management (IPM) to control pests other than pesticides. IPM seeks to reduce pesticide use to the minimum level necessary to produce high-quality food and agricultural products while protecting human health and environmental quality. IPM encourages natural control with beneficial organisms such as predators, parasites, and pathogens. Monitoring, or "scouting," is used to detect pest infestations so that pesticide applications can be targeted to times of need. Such field monitoring can significantly reduce pesticide use while protecting crop yields therefore, reducing the risk of environmental pollution. In New York State, for example, onion growers who followed IPM thresholds based on weekly monitoring reports from field scouts were able to reduce insecticide use by 54 percent and save $\$ 24$ per acre in insecticide costs. Thrips populations were 42 percent lower than those on farms that did not participate in the field scouting program, and the quality of the harvested onions was unaffected (Trautmann et al., 2005). 


\section{CONCLUSION}

The number of pesticides found to be in use along the shore of Lake Naivasha were 141, and ranged from class I to IV. About $18.6 \%$ (26) of these were: extremely hazardous (la) $-0.7 \%$, highly hazardous (lb) $-3.6 \%$ and moderately hazardous (II) $-14.3 \%$. Some pesticides in class I that were being used (e.g. oxamyl, methomyl and fenamiphos are very toxic to human beings and aquatic organisms since they cause cholinesterase inhibition poisoning by reversibly inactivating the enzyme acetylcholinesterase. The quantities of pesticides used were categorized as being high to very high. The pattern of development of pesticide use along the shore of Lake Naivasha was moderate to high and in agreement with that of developing countries. All the farms were also using Integrated Pest Management (IPM) to control pests other than pesticides alone.

\section{ACKNOWLEDGEMENTS}

A lot of gratitude goes to all the farm managers, section supervisors and farm workers who set aside time to fill the questionnaires. Special thanks go to Mr. James Kamau of flamingo farm who assisted in collecting data on levels of pesticide use in the farms. We also appreciate the support of the German Academic Exchange Service (DAAD) for funding this study.

\section{RECOMMENDATION}

1. The use of class I pesticides should be discouraged in order to minimize their effects on health of the workers, communities and water bodies near farms that extensively use pesticides.

2. The use of IPM should be promoted as it improves the efficiency of pest control while at the same time keeping the cost and environmental damage to a minimum.

\section{REFERENCES}

Aspelin AL and Grube AH (1999). Pesticide industry sales and usage: 1996 and 1997 market estimates. United States Environmental Protection Agency.

FAO (1986). International code of conduct on the distribution and use of pesticides. Rome, Food and Agriculture Organization of the United Nations, 28pp.

Fishel FM (2008). Pesticide toxicity profile: Bipyridylium herbicides. Florida Cooperative Extension Service, Institute of Food and Agricultural Sciences, University of Florida. PI-88. (http://edis.ifas.ufl.edu.).

Giavini E and Menegola E (2010). Are azole fungicides a teratogenic risk for human conceptus? Toxicology Letters. 198 (2):10-11.

Jolicoeur JLC (2000). Groundwater contamination potential of agriculture around Lake Naivasha: Comparison of five different unsaturated soil zones. MSc. Thesis International Institute for Aerospace Survey and Earth Sciences (ITC) Enschede, The Netherlands.

Maren K, Ignaz JB, Andrea H, Markus DM and Poiger T (2008). Azole Fungicides: Occurrence and Fate in Wastewater and Surface Waters. Environmental Science \& Technology. 42 (19): 7193-7200.

Mohammad FK (2007). Review of a Practical Electrometric method for determination of Blood and Tissue Cholinesterase activities in Animals. Online Veterinary Journal, Vol. 2, No. 2 (16).

Nathaniel LS, Nathan KT, Jana SL, David HB and Tracy KC (2006). Dose-additive inhibition of chinook salmon acetylcholinesterase activity by mixtures of organophosphate and carbamate insecticides. Environmental Toxicology and chemistry. 25 (5): 1200-1207.

Njoroge SM (2012). Concomitant contributions of pesticide management and transport to groundwater contamination along the shore of Lake Naivasha, Kenya. PhD thesis. School of Environmental Studies, Moi University, Kenya.

Tang ZX (1999). Water Quality Assessment and Pesticide Fate Modeling in the Lake Naivasha area, Kenya. MSc. thesis. Institute of Aerospace Survey and earth Sciences, Enschede, The Nehrerlands.

Trautmann NM, Porter KS and Wegenet RJ (2005). Pesticides and Groundwater: A Guide for the Pesticide User. Natural Resources Cornell Cooperative Extension. Cornell University, Ithaca, NewYork.

Wachter AJM and Staring WDE (1981). Comparative study on the supply, distribution and use of agropesticides in the ESCAP region. Bangkok, Agricultural Division, Economic and Social Commission for Asia and the Pacific (Agricultural requisites scheme for Asia and the Pacific, ARSAP/2/Agropesticides).

WHO (1990). Public Health impacts of pesticides used in agriculture. WHO. Britain. 
US EPA (2007). US Environmental Protection Agency. Office of Pesticide Programs. Interim Reregistration Eligibility Decision for Oxamyl. List A. Case 0253. Washington DC, USA.

WHO (2011). The WHO Recommended Classification of Pesticides by Hazard. Available at http://www.who.int/ipcs/publications/pesticides_hazard/en/\# (consulted June 2011). 